\title{
Flash Floods and Groundwater Recharge Potentials in Arid Land Alluvial Basins, Southern Red Sea Coast, Egypt
}

\author{
F. Abdalla',2, I. El Shamy³, A. O. Bamousa ${ }^{4}$, A. Mansour ${ }^{1}$, A. Mohamed ${ }^{5}$, M. Tahoon 6 \\ ${ }^{1}$ Geology Department, Faculty of Science, South Valley University, Qena, Egypt \\ ${ }^{2}$ King Saud University, Riyadh, Saudi Arabia \\ ${ }^{3}$ Geology Department, Faculty of Science, Helwan University, Cairo, Egypt \\ ${ }^{4}$ Geology Department, Faculty of Science, Taibah University, Madinah, Saudi Arabia \\ ${ }^{5}$ Marine Science Institute, Hurgada Branch, Hurgada, Egypt \\ ${ }^{6}$ Egyptian Environmental Affairs Agency, Red Sea Branch, Hurgada, Egypt \\ Email: fathygeo@yahoo.com
}

Received 12 June 2014; revised 8 July 2014; accepted 5 August 2014

Copyright (C) 2014 by authors and Scientific Research Publishing Inc.

This work is licensed under the Creative Commons Attribution International License (CC BY).

http://creativecommons.org/licenses/by/4.0/

(c) (7)

Open Access

\section{Abstract}

Flash flooding is one of the periodic geohazards in the southern Red Sea Coast. However, their freshwaters are the main source of recharging alluvial and fractured aquifers. This paper presents hydrological and geomorphologic classification of Wadi El-Gemal, Wadi Umm El-Abas, Wadi Abu Ghuson and Wadi Lahmi, along the southeastern Red Sea Coast in Egypt. The main goal is to find a relationship of flash floods and groundwater recharge potentials. Satellite imageries and topographic data were analysed via remote sensing and GIS techniques. The main four valleys' orders range from six to seven. Wadi El-Gemal was the main focus of this study; it is characterized by high stream frequency, low stream density and coarse texture, reflecting influence of highly fractured Precambrian rocks. Most of the wadis have umbrella-shaped catchment areas, due to the influence of NW-SE Najd Fault System and late E-W strike-slip faults. The main wadis were divided into 45 sub-basins. 14 of the studied sub-basins flow into Wadi El-Gemal, 7 flow into Wadi Umm El-Abas, $\mathbf{1 0}$ are in Abu Ghuson, and rest of the basins flow into WadiLahmi. A conceptual model was used in this study, showing that most of the sub-basins have high flash flooding and low groundwater recharge potentials. However, only two sub-basins have low potential of flooding and high potential of groundwater recharge, whereas few sub-basins have moderate potential of groundwater recharge as well as flooding. For flash floods beneficiation and mitigation, construction of multifunctional embankment dams is imminent. 


\section{Keywords}

\section{Flash Floods, Wadi El-Gemal, Groundwater Recharge, GIS, Red Sea Coast, Egypt}

\section{Introduction}

Hydraulic geometry and geomorphologic analysis provide better understanding of alluvial basins nature and occasional geohazards that can obstruct projects of development [1]. Countries located in semi-arid to arid regions, such as Egypt, have alluvial (wadi) systems, formed during fluvial time of the Tertiary and Quaternary periods. These wadis suffer from flash floods, consequent to heavy precipitations. A flood that involves a widespread, runoff flow event in an arid basin were intense showers exceed the infiltration capacity of the soil surface is actually quite different from a major overbank event in the lower reaches of a large river system, driven by excessive persistent basin-wide precipitation [2]. Flash floods occur occasionally in wadis that pour into the Red Sea Coast ata specific time of the year. Yet, they should be taken seriously as natural hazardphenomena.

Different morphometric parameters were used to determine flash flooding potentiality in this study that fall in the arid basin conditions. The first parameter is Bifurcation ratio $(\mathrm{Rb})$, defined as the ratio between the number of stream order $(\mathrm{Nu})$ to the number of the next order $(\mathrm{Nu}+1)$. The basin perimeter $(\mathrm{P})$ is the length of the line that outlined basin area. Stream density (D) is the total length of all the streams in the basin to the area of the whole basin ( $\mathrm{D}=$ total length of streams/basin area). Stream frequency $(\mathrm{F})$ is defined as the number of drainage segments per unit areas [2], in which $\mathrm{F}=\sum \mathrm{Nu}$ (total number)/A (basin area), and it measures the texture of the drainage net. The circularity ratio (Rc) as has been expressed as $\mathrm{Rc}=4 \pi \mathrm{A} / \mathrm{P} 2$; where $\mathrm{A}$ is the area of the basin (size of the contributing drainage area expressed in square kilometers or hectares).

If a basin has a high value of (Rb), this express about a slow surface runoff, gives the chance for water to infiltrate under the surface, and accordingly enriches the underground reservoirs. On the other hand, chance for water to flood will be low and vise versa [2]. The stream perimeter is directly proportional to the area of the basin and the curvature of the basin margins. Basins with low stream density numbers indicate regions of highly permeable or highly resistant subsoil material under dense vegetation. While basins with high stream density numbers indicate appreciable local amount of rainfall, but on the other hand high flood peaks and low contribution to groundwater. If the value of $(\mathrm{F})$ is high, this gives an indicator for the large number of tributaries and also chances for collecting water to the main wadi. Accordingly, the flood chance increase and vice versa. (Rc) has its influence on the hydrologic characteristics such as flow and sediment load yield and the time for concentration of flow to the main channel is less in circular basin than in elongated one [3].

The potentiality of flooding and recharging groundwater for sub-basins in the study area were determined via the El Shamy's Model [3] which explains the relation between the stream frequency (F), the bifurcation ratio (Rb) and stream density (D). The El Shamy's Model contains three fields (A, B and C). Domain (A) represents basins of low stream frequency (F), low stream density (D) and high bifurcation ratio (Rb). Basins of this field may reflect appropriate geologic and geomorphologic conditions with good chances to recharge the existing shallow aquifer and low flood opportunity. Domain (B) includes all basins of low bifurcation ratio (Rb), high stream density (D) and high stream frequency (F). These basins may represent the highest flood probability and the least groundwater potentiality. Domain(C) includes all basins in between class (A) or class (B) boundary conditions. Basins belonging to this field $(\mathrm{C})$ may have moderate recharge of groundwater and moderate flooding potentialities.

Flash floods in arid and semi-arid zones are among the most devastating natural hazards in the world, causing the largest number of deaths and property damages. They occur as a result of high-intensity rainy storms over catchment areas which have steep slopes and poor vegetation cover, producing sudden and high velocity flows [4]. Absolute protection against flooding is unachievable and unsustainable, due to high cost and inherent uncertainties [5]. In addition, numerous mechanisms involved in the generation of floods, which make them highly unpredictable.

A growing concern in Egypt for embracing a more socially and environmentally responsible tourism business model has been raised, while there are still opportunities for traditional large resort properties. Sustainable development along the eastern Red Sea Coast has accelerated rapidly in the past three decades. However, flash 
floods as major natural hazards bring considerable concern for infrastructures and other development works in the area, when they occur. Sustainable tourism accommodation options "ecolodges" are found suitable by the Egyptian Tourism Development Authority, for areas such as Wadi El Gemal-Hamata Protected Area (WGHPA). The WGHPA includes over $50 \mathrm{~km}$ of pristine coastline that includes coral reefs, sensitive sea turtle nesting habitat, and beautiful beaches. The area between Wadi El-Gemal and Wadi Abu-Ghuson includes the WGHPA, which is proposed to be a natural park that has ecolodges and ecotourism activities. South of Abu-Ghuson port, the Mangrove trees (Avicenna marina sp.) extend along the intertidal and the coastal zone for about $14 \mathrm{~km}$, and tens of migratory and resident birds species attract visitors from all over the world. Moreover, beaches in WGHPA remain one of few places that tourists can enjoy unspoiled coastal landscapes.

In the neighboring countries, such as Saudi Arabia, occasional flash floods along the Red Sea also bring disastrous consequences to the coastal cities. An occurrence of such a flood in Jeddah during the winter of 2009 caused significantly high lossesof properties and lives [6] [7]. In the winter of 2013, flash floods significantly affected the city of Tabuk, a north-western Saudi city, instigating hazardous mud flows, landslides and land subsidence. Therefore, they are currently considered as a major geohazard, by both public and privatesectors.

Pure geomorphologic studies are under-estimated for flash flood management and assessment for their lack of quantitative parameters [1]. Thus, Geographic Information System (GIS), spatial and microwave remote sensing applications are powerful tools for assessment and management of flood hazards [8]-[12]. They provide a statistical approach for hydrological studies and give a synoptic view of large area precisely. Satellites that are similar to Tropical Rainfall Measuring Mission (TRMM), Geostationary Satellite Server (GOES), METEOSAT, Geostationary Meteorological Satellite (GMS), and Indian National Satellite (INSAT) are real-time meteorological events recorders, such as rainfall and wind movements [11]. These are interactive weather satellites that can help in recording severe events during their occurrences, such as thunderstorms and tornadoes.

The aim of this study is to create a meaningful hydrological and morphological classification of major wadis in south-eastern Red Sea Coast of Egypt. In addition, it provides a model that may reflect flash flood and groundwater aquifer potentials. It finally might play a vital role in groundwater replenishment and to avoid surface runoff and damaging infrastructures in the study area.

\section{The Study Area}

The study area is characterized by an arid climate, varies from hot and rainless summer to extremely dry winter. The Tourism Development Authority reported that the region receives occasional very heavy rains over a short period; such rains can cause flash floods [13]. Average rainfall is equal to $17.4 \mathrm{~mm} / \mathrm{y}$, and the greatest amount of rainfall precipitation, $13 \mathrm{~mm}$, was recorded in November 2004. The mean annual relative humidity is $43 \%$ and the mean annual evaporation rate is $16.8 \mathrm{~mm}$. Infiltration capacity of the top soil in the study area describes the passage of surface water into the ground for recharging shallow groundwater aquifer. Five infiltration tests using the double ring infiltrometer were carried out. The measured infiltration rate ranges between $1.33 \mathrm{~m} / \mathrm{day}$ to 8.18 $\mathrm{m} /$ day [14].

The weather system in the autumn and winteris associated sometimes with heavy and episodic localized downpours, causing flash floods that may affect roads and sporadic settlements. The study area extendsfor up to $130 \mathrm{~km}$ along the Egyptian Red Sea Coast and for about $60 \mathrm{Km}$ to the west through the Precambrian rocks of the Eastern Desert (Figure 1). The area comprisesfour main wadi type basins, including Wadi El-Gemal, Wadi Umm El-Abas, Wadi Abu Ghuson and WadiLahmi, between the town of Marsa Alamin the North and Baranes in the South. They are located between longitudes $34^{\circ} 54^{\prime}$ and $35^{\circ} 34^{\prime}$, and latitudes $24^{\circ} 6^{\prime}$ and $25^{\circ} 4$ '.

Hydrographically, the study area could be subdivided into three terrains; the watershed zone, the water catchment zone andthe coastal plain zone. The watershed zone reflects high mountains and hillsto the west of the Red Sea. Most of rainfallsover this area, flow towards the west, and pour into the coastal plain drainage system. However, many rainfalls pour into Red Sea drainage system. The second geomorphic area is the water catchment zone; it occurs between the watershed terrain and the coastal plain, and it plays a considerable role in recharging the shallow groundwater aquifers in the area. The Marsa Alam-Baranes district comprises two types of water storage areas, i.e., the morphotectonic depressions and hydrographic (drainage) basins. The third hydrographiczone is 2 - $12 \mathrm{~km}$ flat coastal plain along the Red Sea Coast. Recent gravels and sanddeposits form the alluvial terraces and beaches in this zone, which at several places, aredissected by narrow and wide wadis.

Quseir region, north of the study area, has witnessed several heavy rainfalls, followed by flash floods. The 


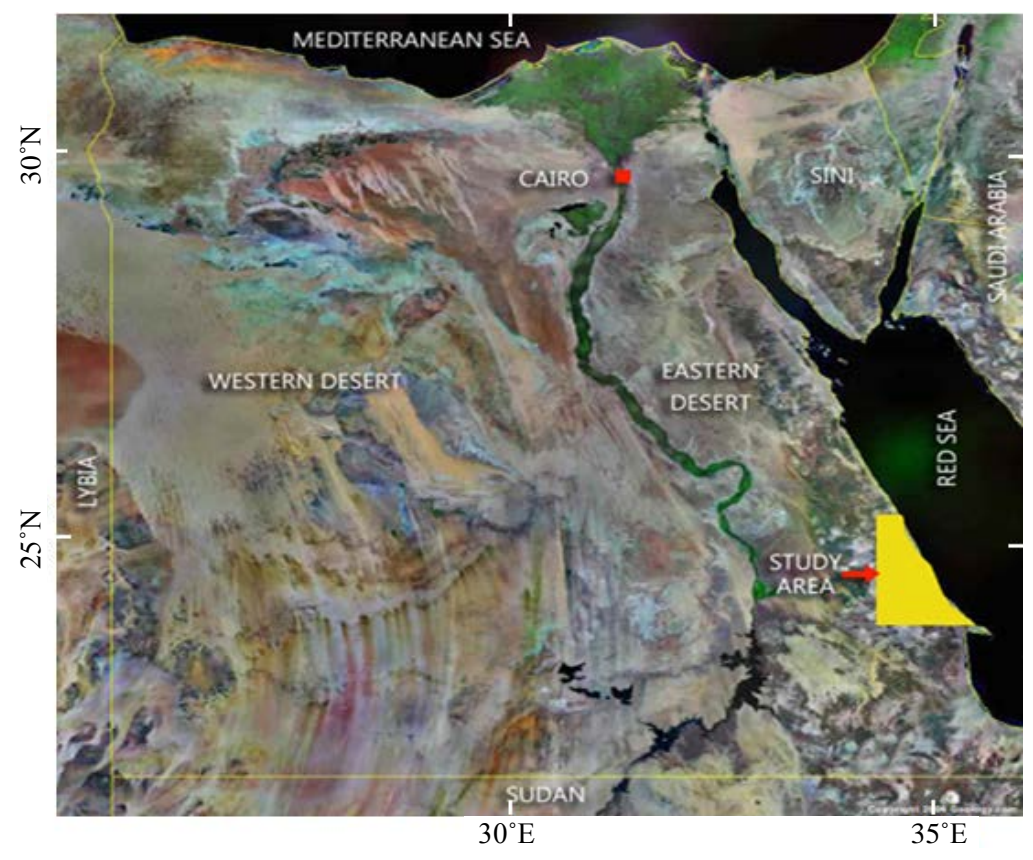

Figure 1. Location map of the studied basins.

records suggest that rainfall events in the region are more expected than before. The region was affected by rainfalls and flash floods in October 1979, October 1990, and November 1996, suggesting high possibilities of flash floods occurrence. Similarly, the Hafafit area received heavy rains and consequent flooding on $9^{\text {th }}$ September 2004, in the Wadi El-Gemal, Abu Guson and Lahmion $6^{\text {th }}$ November 2004, and on $28^{\text {th }}$ December 2010 (Figure 2). This figure shows fresh water mixed with sediments and clay that could be more destructive than just rain water. This suggests that the possibility of heavy rains and consequent flash floods has increased from an event per 9 years to an event per 6 years in the area, probably due to climate changes and global warming effects [15].

\section{Geologic Setting}

Precambrian rocks constitute the major rock units of the study area, overlain mainly by $2-12 \mathrm{~km}$ wide coastal area that consists of Tertiary rocks and Quaternary sediments. The Tertiary rocks are mainly Miocene evaporites and Pliocene continental and marine beds, forming a belt of coastal hills that overlie transgressive Miocene dolomites. In the area between Wadi El-Gemal and Wadi El-Ranga, the Oligocene Abu Ghuson Formation unconformably overlies the Precambrian rocks and underlies the Ranga Formation. The Upper Cretaceous Tarfi Formation is represented by yellow-yellowish grey and cross bedded small outcrops in Wadi El-Ranga. Basel part of this formation is dominated by hard sandstone and conglomeratic beds. The Quaternary sediments in the area form sand dunes and terraces along the coast as well asthe banks of the wadis. Groundwater is mainly preserved in the Quaternary wadi deposits, and in the Tertiary sandstone and conglomerate rocks. The hydrochemical parameters of the groundwater in the study area reflect more seawater than fresh water parameters. The dominant anions occur in the following sequence: $\mathrm{Cl}>\mathrm{SO}_{4}>\mathrm{HCO}_{3}$, while the dominant cations are $\mathrm{Na}>\mathrm{Mg}>\mathrm{Ca}$ [15].

Structural analysis of the Precambrian complex reveals mainly four deformational events, occurred during geologic historyof the study area [16]. The NW-trending folds in the area represent the oldest deformational event, cross-cut by NE-dipping low-angle thrust faults. The second event represented by NW-SE directed left lateral strike slip faults, which may belong to the Najd Faults System (NFS). The third deformational event represented by E-W trending left lateral strike-slip faults with neglected vertical component. Structure of this event, is cross-cut by NNW-SSE right lateral strike-slip faults. Highly fractured Precambrian rocks form a secondary porosity in areas such as the Arabian Shield [16] [17]. They reflect high stream frequency, low stream density, and coarse texture. The subsequent structural features may control wadis which flow into the Red Sea Coast, forming umbrella-shaped basins for most of the wadis of the study area. 


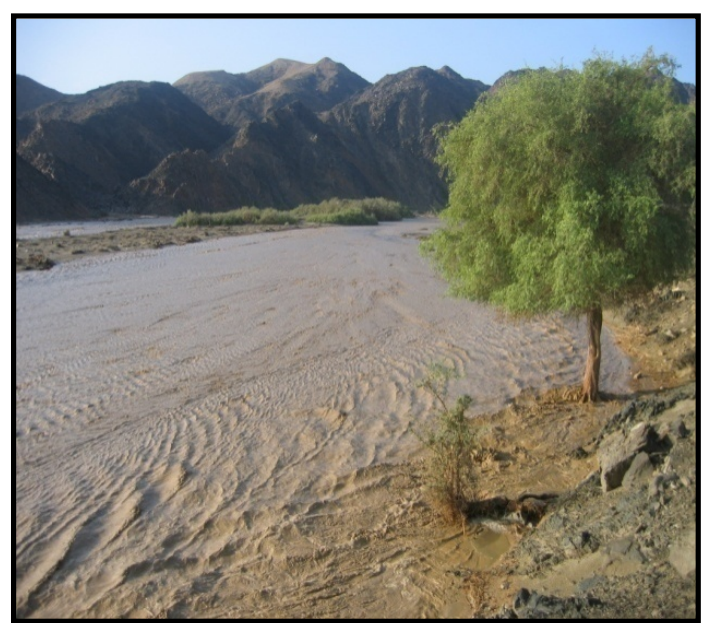

(a)

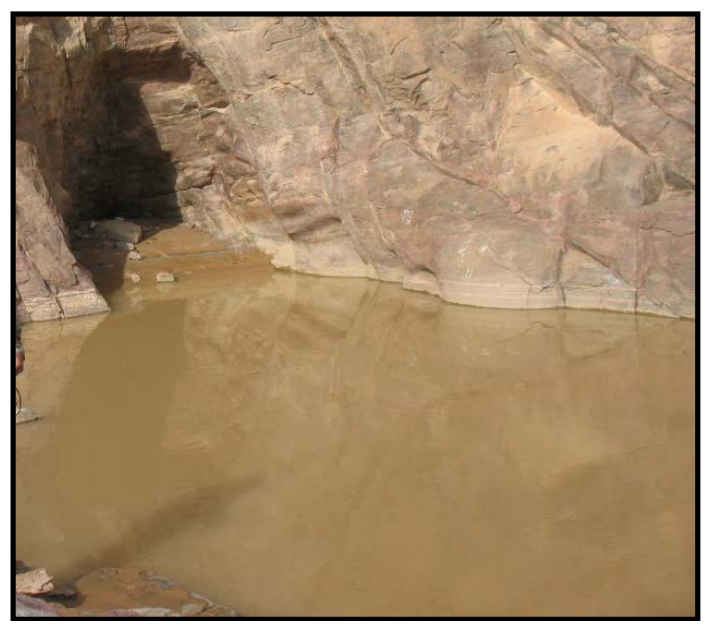

(b)

Figure 2. Field photographs show rains and floods of Wadi El Gemal basin (a) in the $6^{\text {th }}$ of November 2004 and (b) in the $28^{\text {th }}$ of December 2010.

Two morphotectonic depressions have been recognized in the study area; Abu Ghuson depression in the north, and Baranes depression in the south [18]. The Abu Ghuson depression is bounded by hills of metagabbro, diorite and middle Miocene rocks to the east and Gabal Hamata in the west, while Baranes depression isbounded by Precambrian rocks.

\section{Methodology and Results}

Drainage basins morphometry was determined via GIS techniques using ArcGIS (version 9.2). Satellite images of landsat TM7 sensor were used as base maps for the GIS technieques. These images were enhanced by False Color Composite of bands 7, 4, 2 in Red, Green, and Blue filters. The Acquisition year is 2003, projection type is UTM, spheroid name is WGS84, datum name is WGS84, UTM zone is WGS84, and pixel size is 28.5 meter. The 1:250,000 scale geologicalmap, prepared by Egyptian Geologic Survey in 1997, is used to get the geologic setting of the area. Table 1 shows the measured morphometric parameters of streams and sub-basins of the four wadis. The streams parameters are their order, number and length. The sub-basins parameters are their length, area, perimeter, sinuosity, bifurcation ratio, stream density, drainage frequency, circularity ratio, shape index, relief ratio, ruggedness number, gradient, texture ratio, and valley length.

The morphometric characterization and basins delineation were produced using topographic maps of different scales (1:50,000, 1:100,000 and 1:250,000).

Four hydrographic wadi basins were selected for this study; from north to south, Wadi El-Gemal, Wadi Umm El-Abas, Wadi Abu Ghuson and WadiLahmi (Figure 3). All these wadis drain into the Red Sea, cut the main roads between MarsaAlam and Shalateenand pass through the touristic spots and populated areas. They were subdivided into 45 sub-basins in order to identify the relationship between flash flood occurrence and groundwater recharge. Wadi El-Gemal basin is the largest basin in the study area $\left(1951 \mathrm{~km}^{2}\right)$. A large number of local people live in this wadi, for its high groundwater resources and vegetation cover. This basin also is characterized by mining activities, such as feldspar and quartz mines. For all these reasons, this study focused mainly on Wadi El Gemal basin; hence, it analyzed in details.

\subsection{Wadi-El-Gemal Morphometry}

Wadi El-Gemal basin (Figure 4) have umbrella-shaped catchment area; its drainage net is well developed, integrated, dense and has variable angles of junctures. The basin drains through high mountains with steep slopes, especially in the upstream part, in which elevation reaches up to $1856 \mathrm{~m}$. Significant large channels are mostly arranged in parallel to subparallel patterns with dendritic to subdendritic tributaries. The main wadi is oriented NNW in the upper part, E-W in the middle part and NE near the mouth (Figure 4). Its large tributaries are mostly running NW and NNE, mostly due to fault control. The main trunk wadi at the lower part is narrow, 


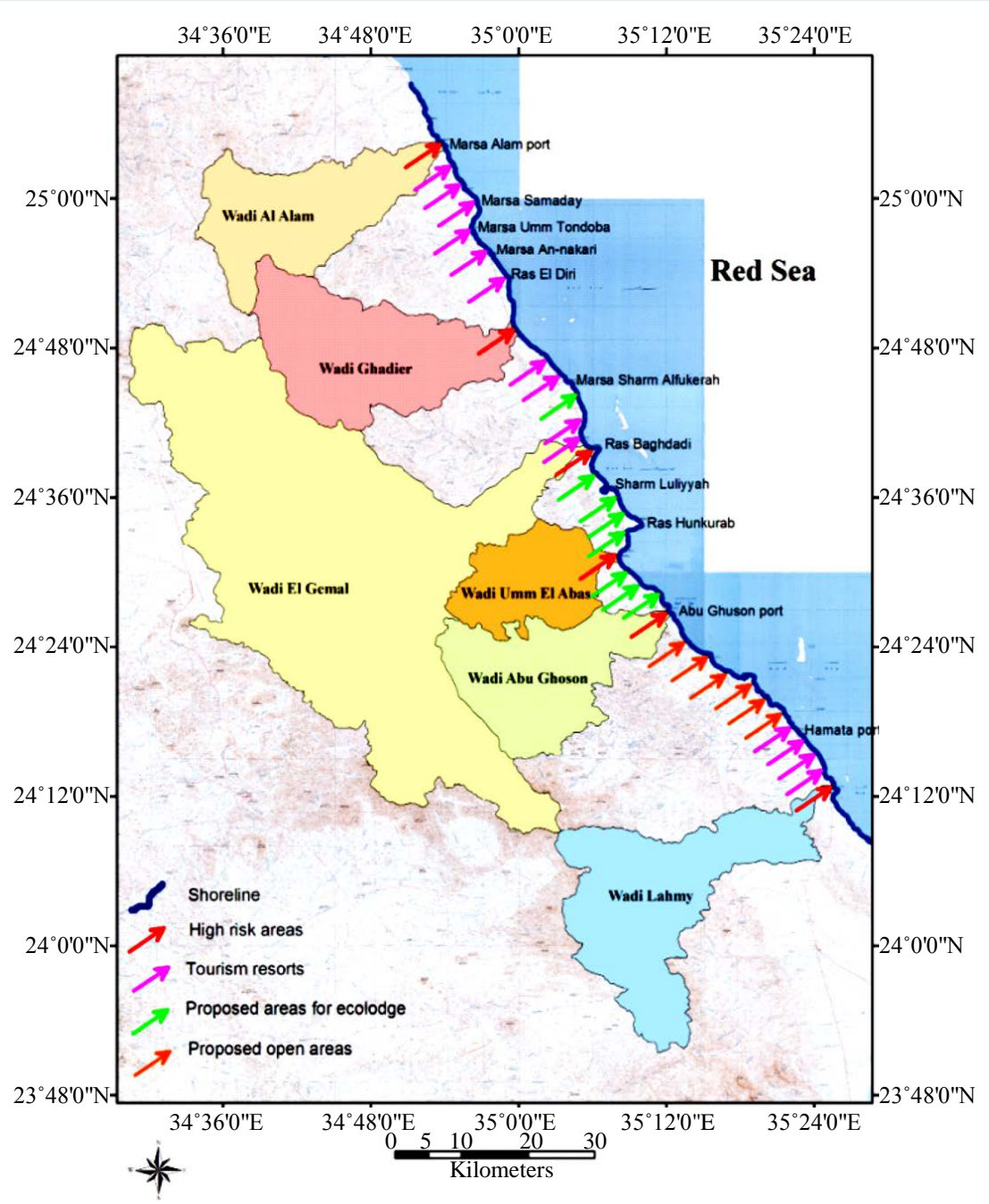

Figure 3. The studied hydrographic basins showing areas of flash flood possibilities, locations of tourism resorts and proposed sites for ecolodge and open areas.

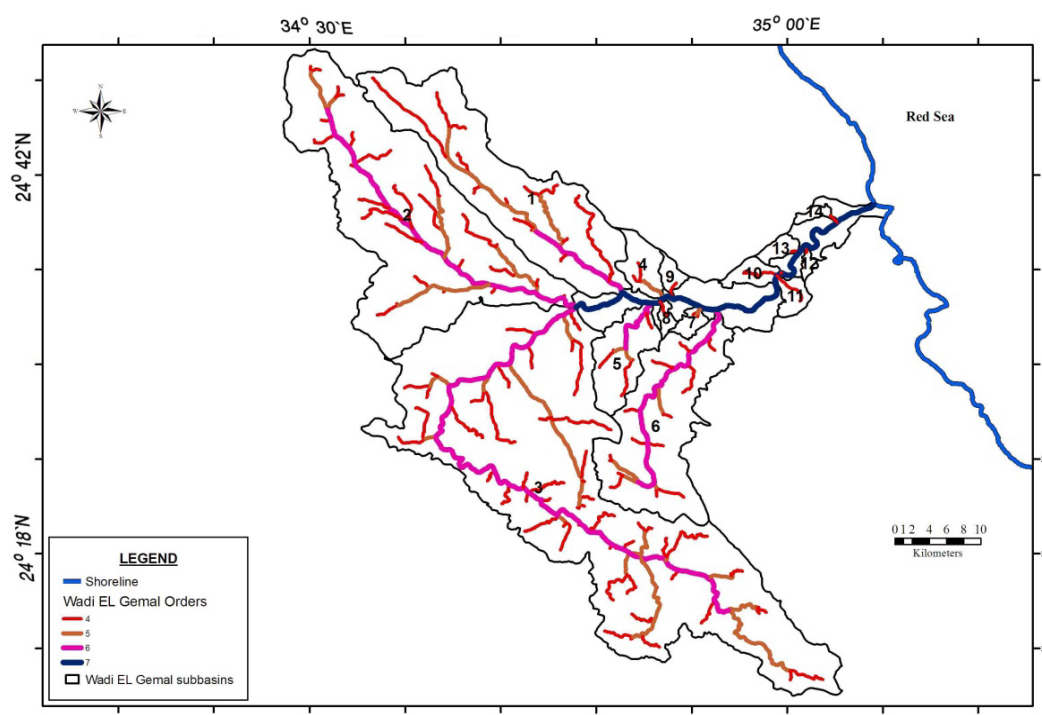

Figure 4. Drainage pattern and sub-basins of Wadi El Gemal basin. 
Table 1. Basic morphometric parameters of the studied basins.

\begin{tabular}{ccccc}
\hline Basic Parameters & Wadi El Gemal Basin & Wadi Umm-El Abbas Basin & Wadi Abu Ghuson Basin & Wadi Lahmi Basin \\
\hline U & 7 & 7 & 6 & 6 \\
SNu & 12,717 & 2189 & 2702 & 905 \\
SLu & 7181.1 & 1511.6 & 1509.9 & 924.6 \\
LB (km) & 63.2 & 25.2 & 31.9 & 43.4 \\
A (km $\left.{ }^{2}\right)$ & 1951 & 257 & 403 & 577 \\
W (km) & 61.3 & 12.8 & 13.7 & 15.3 \\
P (km) & 339 & 94 & 127 & 181 \\
Si (km) & 1.954 & 1.2514 & 1.1743 & 1.4139 \\
Rb & 4.71 & 3.55 & 4.63 & 3.84 \\
SF & 6.9 & 5.8 & 6.7 & 4.57 \\
SD & 3.7 & 3.5 & 3.7 & 3.22 \\
Rc & 0.21 & 0.37 & 0.31 & 0.22 \\
Ish & 0.620 & 0.514 & 0.503 & 0.389 \\
R (km) & 1.852 & 0.746 & 1.244 & 1.559 \\
Rr & 0.029 & 0.030 & 0.039 & 0.036 \\
Rn & 6.82 & 2.62 & 4.66 & 5.01 \\
S\% & 0.33 & 0.60 & 0.50 & 0.38 \\
Rt (km $\left.{ }^{-1}\right)$ & 39.6 & 15.9 & 21.3 & 5.0 \\
VL (km) & 123.5 & 31.5 & 37.5 & 61.4 \\
\hline
\end{tabular}

$\mathrm{U}=$ order of trunk channel, $\mathrm{W}=$ basin width, $\mathrm{SD}=$ stream density, $\mathrm{SNu}=$ sum of trunk number, $\mathrm{P}=$ basin perimeter, $\mathrm{Rc}=$ circularity ratio, $\mathrm{SLu}=$ sum of stream lengths, $\mathrm{Si}=$ sinuosity, $\mathrm{Ish}=$ shape index, $\mathrm{LB}=$ basin length, $\mathrm{Rb}=$ bifurcation ratio, $\mathrm{R}=$ relief, $\mathrm{A}=$ basin area, $\mathrm{F}=$ stream frequency, $\mathrm{Rr}=$ relief ratio $(\mathrm{R} / \mathrm{LB}), \mathrm{Rn}=$ ruggedness number, $\mathrm{S} \%$ = gradient, $\mathrm{Rt}=$ texture ratio $(\mathrm{Snu} / \mathrm{P}), \mathrm{VL}=$ valley length .

which might indicates a high potential of flash floods at the downstream part of the trunk wadi. The basin mouth is crossed by the Red Sea Coastal road for about $2 \mathrm{~km}$ long distance. Wadi El-Gemal has two main wells, Wadi El-Gemal well (WG1), located in its upstream part, and Al Abyad well, located in Wadi Al Abyad.

Morphometric parameters of Wadi El-Gemal basin were calculated and are shown in Table 1. Wadi ElGemal basin is a $7^{\text {th }}$ order valley, and the basin has $(\mathrm{Rb})$ value greater than 3 which reflects highly dissected and mountainous areas [19]. The high Rb value gives an indication that the basin has a slow surface flow, which allows water to penetrate through the soil sediments and enrich the groundwater aquifer and decrease flash flood development.

The Wadi El Gemal basin has a perimeter equal to $339 \mathrm{~km}$ in length, and the length of the main channel is about $44 \mathrm{~km}$. The stream frequency is high (6.9) and the stream density is low (3.7) and coarse texture is (39.6); this is probably due to the prevalence of highly fractured and faulted Precambrian rocks. The basin shape index has its influence on the hydrologic characteristics such as flow and sediment load, in which the high load of sediments increases damages of floods [11]. In comparison with the other basins, Wadi El-Gemal has the lowest (Rc) value (0.21), indicating less circular shape than the other basins. This suggests that time for the flow to accumulate in the main channel is more than the time needed in the circular basins [20].

Wadi El-Gemal basin can be divided into 14 sub-basins; these sub-basins are Wadi Nuqrs, Wadi Hafafit, Wadi Hulus, Talat Umm Al-Jiran, Wadi Mukhattata, Wadi Al-Abyad, Talat Umm Suwayh Al-Qasirah, Talat Umm Itlat, Talat Umm Kabu, Talat Umm Sayyal, Kab Al -Khawwarah, Far At Tanash, Khawr Umm Hajalijah, and Talat Umm Bisay. Wadi Hulus is the largest sub-basin in the area of study $\left(802 \mathrm{~km}^{2}\right)$. It is located in the southwestern part of Wadi El-Gemal basin and drain through Hamata mountains towards the main trunk of Wadi El-Gemal basin. It is a sixth order valley; its registered texture ratio is 30.9 and the valley length is $88 \mathrm{~km}$. Also Wadi Nuqrs, Wadi Hafafit, Wadi Mukhattata and Wadi Al Abyad have a large area that ranges from $57 \mathrm{~km}$ to $437 \mathrm{~km}^{2}$, and they are sixth order valleys. These four sub-basins with Wadi Hulussub-basin are considered the main sub-basins in Wadi-El Gemal basin. 
Potentials of flash flood and groundwater aquifers recharge were compared in accordance with El Shamy's Model [3] [19], using some morphometric parameters of these basins (Figure 5). The hydrological and geomorphic characteristics of the basins indicate moderate recharge conditions of shallow aquifers and moderate possibilities of flooding (Figure 5). Some of sub-basins have more flooding chances than others. Concerning the sub-basins of Wadi El-Gemal hydrographic system, it is noteworthy that the widely spreading adjacent upstream sub-basins (Hulus, Nuqrs, and Hafafit) occupying domains A \& C (Figure 6). This might reflects a relatively moderate to high potential of recharging shallow and fractured aquifers and limited to moderate flooding opportunity.

Two sub-basins in the middle and downstream parts of Wadi El-Gemal hydrographic system occupy domain C, and 9 sub-basins occupy domain B (Figure 6), suggesting moderate to high flooding occurrence and moderate to low recharge of groundwater aquifers. Consequently, such sub-basins should be supported with adequate retardation dam system for increasing recharge conditions and reducing flash floods possibilities. The retardation dams assist slow movement of runoff, and facilitate downward water infiltration from the flood plains of such wadis to the shallow weathered and fractured zones of basement rocks.
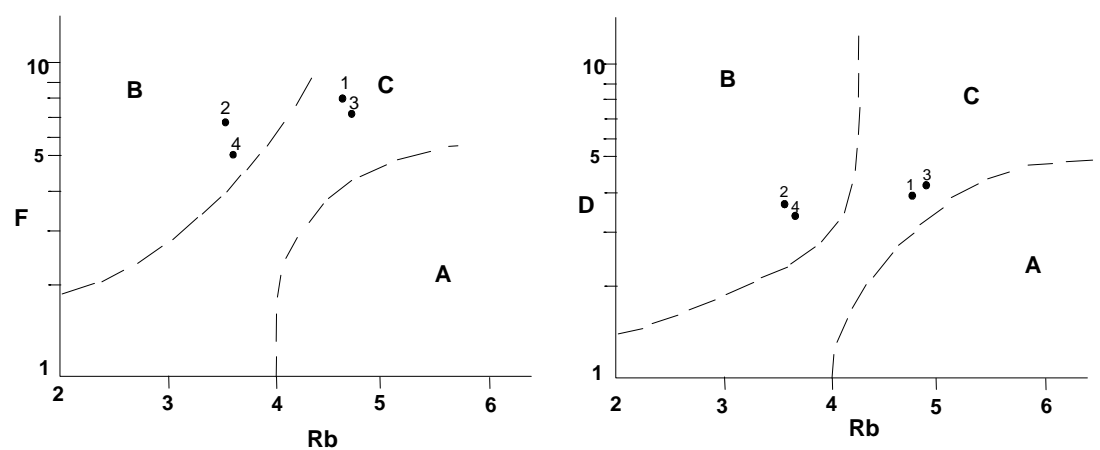

Designations: Rb: Bifurcation ratio, F: Stream frequency, D: Stream density, A: Low flood possibilities,

B: High flood possibilities, C: Intermediate flood possibilities

$$
\begin{array}{ll}
\text { 1= wadi El Gemal } & \text { 3= wadi Abu Ghuson } \\
\text { 2= wadi Umm El Abas } & \text { 4= wadi Lahmi }
\end{array}
$$

Figure 5. Flash floods and groundwater recharge possibilities of the four basins using some hydro-morphometric parameters based on El Shamy’s Model [2].

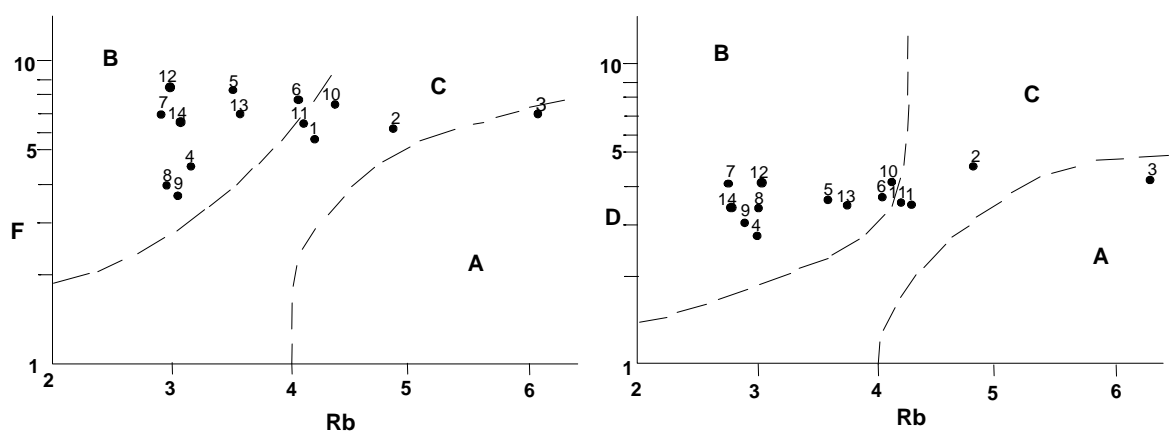

Designations: Rb: Bifurcation ratio, F: Stream frequency, D: Stream density, A: Low flood possibilities,

B: High flood possibilities, C: Intermediate flood possibilities

$\begin{array}{lll}\text { 1= wadi Nuqrs } & \text { 6= wadi Al Abyad } & \text { 11= Kab Al Khawwarah } \\ \text { 2= wadi Hafafit } & 7=\text { Talat Umm Suwayh Al Qasirah } & \text { 12= Far At Tanash } \\ \text { 3= wadi Hulus } & \text { 8= Talat Umm Itlat } & 13=\text { Khawr Umm Hajalijah } \\ \text { 4= Talat Umm Al Jiran } & 9=\text { Talat Umm Kabu } & 14=\text { Talat Umm Bisay } \\ \text { 5= wadi Mukhattata } & \text { 10= Talat Umm Sayyal } & \end{array}$

Figure 6. Flash floods and groundwater recharge possibilities of Wadi El Gemal sub-basins using some hydro-morphometric parameters based on El Shamy's Model [2]. 


\subsection{Wadi Umm El-Abas Morphometry}

This basin is the smallest ( $257 \mathrm{~km}^{2}$ ) among the studied basins, which is nearly circular in shape and favourably has ashort runoff distance. The pattern of this basin is dendritic to sub-dendritic in the upper part and parallel to sub-parallel in the middle part. Flow direction in the trunk Wadiis N-NE in the upper and lower parts and N-NW in the middle part. Substantial segments of these channels are controlled by local faults. It is a $7^{\text {th }}$ order valley, has a perimeter of about $94 \mathrm{~km}$ and is characterized by low stream density (3.5), low relief ratio (0.03) and short channel $(7 \mathrm{~km})$.

Many parts of Wadi Umm El-Abasbasin are currently occupied by local population, which make it suitable for future developments and tourism activities. Three wells were drilled in Umm El-Abas area, using rotary drilling machine and tapping the confined aquifer due to the presence of impermeable clay layer. Two of them (EL1 and EL2) were drilled in Sahl Al Andidibat in the south-western side of Wadi Umm El-Abas basin, and the third one (EL3) was drilled in the main channel part of the Wadi.

The main basin of Wadi Umm El-Abas is divided into 7 sub-basins, Al Nijaybawi, Umm El-Abas, UmmHajin, Al Qamh, Sahl Al Andidibat, Kab Al-Ahmar, and Abas 1 wadis. A 36 km long Wadi Al-Qamh is recognized as the largest sub-basin $\left(75 \mathrm{~km}^{2}\right)$ among them, having the characteristics of $6^{\text {th }}$ order valley. Abas $1\left(37.6 \mathrm{~km}{ }^{2}\right)$ and Sahl Al Andidibat (31.9 $\mathrm{km}^{2}$ ) are two other large sub-basins in Wadi Umm El Abas.

Wadi Umm El Abas basin occupies domain B, indicating high flooding possibility and limited recharge of the shallow and fractured aquifers. Only two sub-basins of Wadi Umm El-Abas hydrographic system occupy domain $\mathrm{C}$, while the other five sub-basins occupy domain B, and there is no sub-basins occupying domain A. This suggests moderate to high possibility of floods and moderate to limited recharge potentialities to the shallow and fractured aquifers.

\subsection{Wadi Abu Ghuson Morphometry}

Wadi Abu Ghuson basin is characterized by rugged and mountainous relief (up to $1247 \mathrm{~m}$ height) with very steep slopes, particularly along and near the water divide. The main channel and long tributaries exhibit variation in segments width, degree of channel incision and channel trends mostly due to structural control of faults, and due to variation of rocks type. The basin parameters are given in Table 1. Abu Ghuson basin is divided into 10 sub-basins.

Wadi Abu Ghuson basin drains through Abu Ghuson village, and has agricultural activities in the downstream part and mining activities of iron oxides mines and granite quarries in the middle parts. Wadi Abu Ghuson basin contains six wells (AG1, AG2, AG3, AG4, AG5 and AG6) drilled in its downstream part. These wells are located 4 to $6 \mathrm{~km}$ far from the coastal area. Wadi Abu Ghuson basin occupies domain C (Figure 6), indicating moderate recharge condition of shallow aquifers and moderate floods possibility. Wadi Ghuson 9 sub-basin is the only one which occupies domain A, which reflects relatively high rechargeable groundwater aquifers and limited flooding possibility where Abu Ghuson village and agricultural activities spread out. The north-western and northern sub-basins (No. 1, 3 \& 8) and two of the southern basins (No. 5 \& 6) occupy domain C, indicating moderate recharge condition of shallow aquifers and moderate possibility of floods. The other sub-basins (No. 2, 4, 7 \& 10) occupy domain B, suggesting low recharge potentiality of shallow aquifers and high possibility of floods.

\subsection{Wadi Lahmi Morphometry}

Wadi Lahmi basin is located in the southern part of the study area (Figure 3). The basin parameters are given in Table 1. The main basin of Wadi Lahmi is divided into 14 sub-basins. It is characterized by steep slope of the upstream part and the narrow width of downstream part. It debouches violently into the Red Sea. This hinders the building of broad delta. Consequently, its coastal plain is crossed by a short segment of the Red Sea Coastal road, which is potentially having high flood possibility.

In spite of the main channel steepness of Wadi Lahmi basin, it has a large number of wells near local people settlements, in addition to safari trips and tourism activities. Wadi Lahmi well (LH1) was drilled nearly in the middle part of the wadi. The water table was registered at $47.5 \mathrm{~m}$ depth from ground surface. Five productive hand-dug wells (LH2, LH3, LH4, LH5 and LH6) were drilled in the upstream part of Wadi Lahmi basin by World Food Program. These wells may occur due to the highly fractured nature of the rocks and the occurrence of intervening plain areas that preserve some of runoff water. 
Wadi Lahmi basin occupies domain B (Figure 5), indicating high flooding possibility and limited recharge of shallow and fractured aquifers. Among all of the sub-basins of Wadi Lahmi hydrographic system, the upstream Wadi Sifint sub-basin (No. 4) is the only sub-basin which occupies domain A. It reflects relatively high rechargeable groundwater aquifers and limited flooding possibility. Most of the western upstream sub-basins occupy domain $\mathrm{C}$ which reflects moderate flooding and recharging conditions. Small seven sub-basins in the middle and downstream parts occupy domain B which suggests high flooding and limited recharge conditions of the shallow and fractured aquifers.

\subsection{Flash Flood Beneficiation}

Beneficiation of such floods can be achieved, using several methods; among of them is the retardation dams that mitigate the runoff velocities. These dams can be formed by loose heaps of accumulated boulders (Figure 7(a)) that consist of weathering products of the rocks without cementation [3]. Moreover, incomplete alternating embankment dams, also known as flood retention or multi-functional dams, should be constructed to form a zigzag path for the courses of floods, between the upstream and downstream areas (Figure 7(b)). Such a system will assist optimum utilization of flash flood water over different parts of the hydrographic basins, preventing severe flash floods, protecting soil cover from drift, and raising groundwater levels by infiltration.

According to the morphometric analysis and land uses, several dams sites are proposed for the four main basins, illustrated in Figure 8. The selected dam sites were at narrow parts of gentle slope courses of selected small basins to retain water, to reduce flow velocity and to promote recharging the alluvial aquifers. This is besides the availability of local materials in the form of loose boulder dams, by accumulating boulders of weathering products without cementation. Dimensions of each heap depend on the local geologic and geomorphologic conditions of its site.

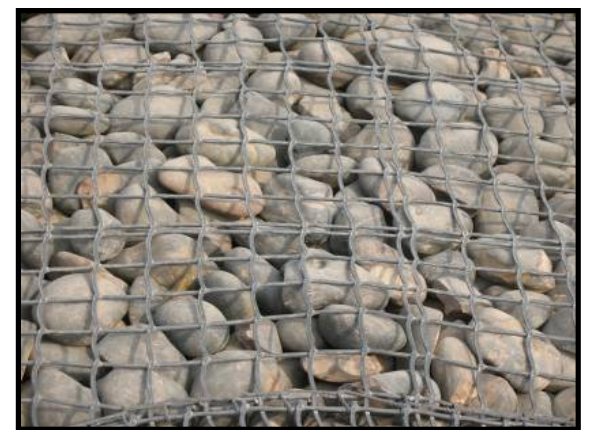

(a)

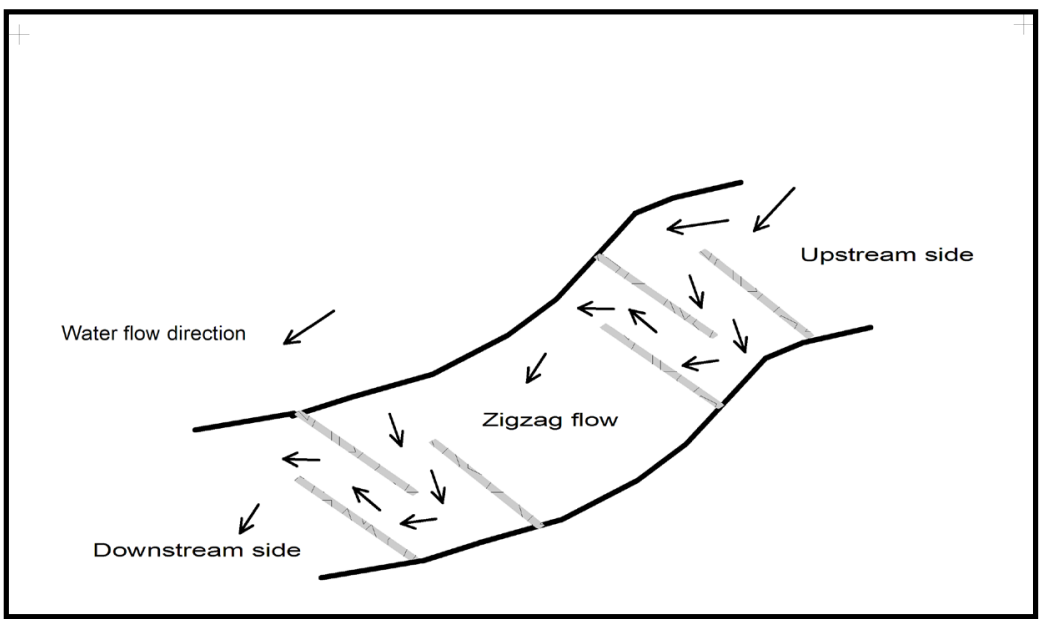

(b)

Figure 7. Diagram showing loose boulders embankment dam fortified by wirenetting and gabions (a) and zigzag path formed by spur dyke dams (b). 


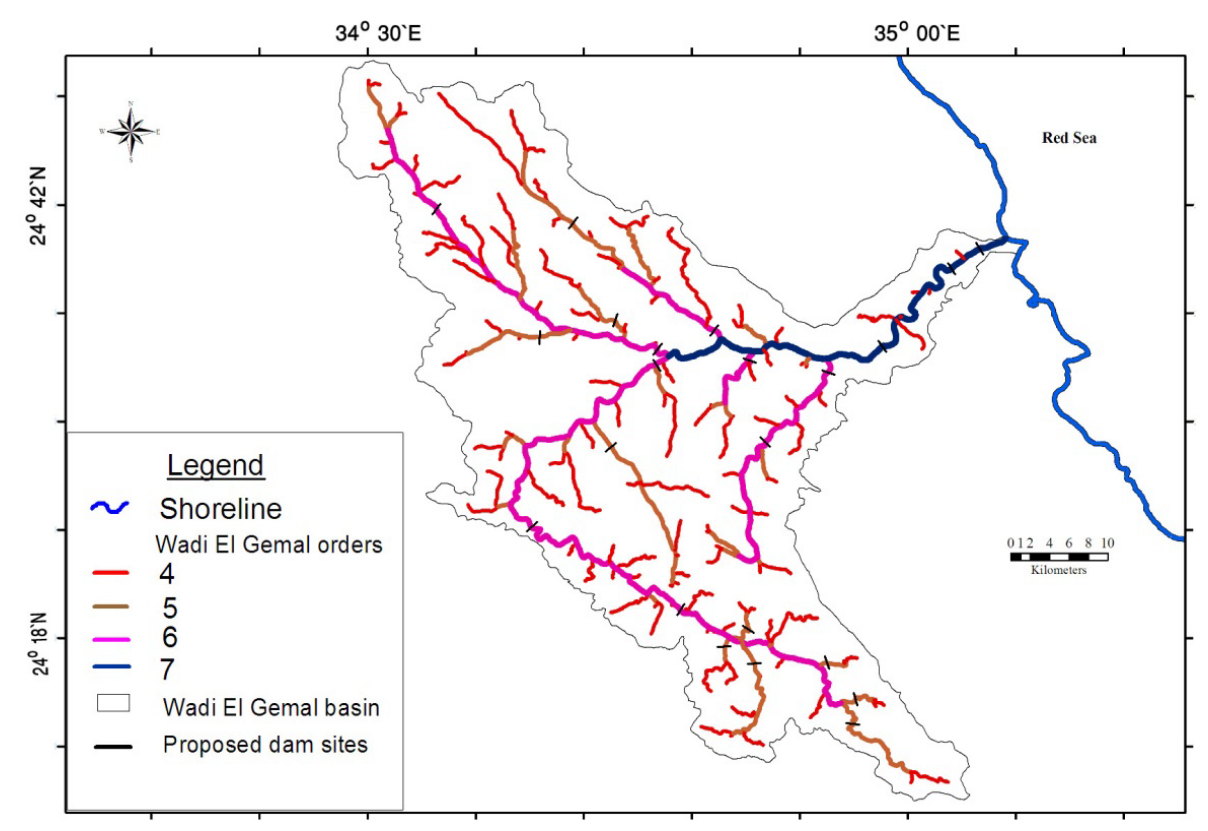

Figure 8. Drainage pattern of the higher four stream orders of Wadi El Gemal basin showing the proposed locations of flood retention dams.

\section{Conclusions}

For flash flood beneficiation and recharging shallow groundwater aquifers, flood plain areas should be opened as much as possible to accommodate stream overflow. Wadis should be excavated to keep streambeds wide, open, and deep; thus, peak flow can pass through easily and rapidly. Adequate numbers and different sizes of bridges should be built for passages. Embankment dams should be used to allow water to spread onto adjoining areas and mitigate flood by spreading water overflow over a larger area.

In the present work, GIS-based morphometry and satellite imagery data are used for the flash floods occurrence and groundwater aquifers recharge relationship, along the Southern Red Sea Coastal area. For each of the 45 sub-basins, a conceptual model was used to assess the potential for flash floods and groundwater recharge. The morphometric parameters of the 45 sub-basins suggest low to moderate groundwater aquifers recharge and medium to high flash floods chances. Only two sub-basins indicate low potential of flooding and high potential of groundwater aquifers recharge. The outlets of the four basins are considered as having high flooding conditions, and are not recommended to be for building any stable constructions. The coastal zone area can be classified into four categories, high flooding area, tourism villages area, ecolodges and natural parks areas as well as rest and open areas (Figure 3). This study recommends avoiding huge concrete buildings in the study area, especially in WGHPA; alternative option is the ecolodge designs and light structures.

\section{Acknowledgements}

The authors are grateful to the reviewers for their suggestions and comments.

\section{References}

[1] Jame, A. (1999) Time and the Persistence of Alluvium: River Engineering, Fluvial Geomorphology, and Mining Sediment in California. Geomorphology, 31, 265-290. http://dx.doi.org/10.1016/S0169-555X(99)00084-7

[2] Horton, R. (1945) Erosional Development of Streams and Their Drainage Basins: Hydrophysical Approach to Quantitative Morphology. Geological Society of America Bulletin, 56, 275-370. http://dx.doi.org/10.1130/0016-7606(1945)56[275:EDOSAT]2.0.CO;2

[3] El Shamy, I. (1992) Recent Recharge and Flash Flooding Opportunities in the Eastern Desert, Egypt. Annuals of Geological Survey of Egypt, 18, 323-334.

[4] Xiao, L. (1999) Flash Floods in Arid and Semi-Arid Zones. International Hydrological Program, Technical Documents 
in Hydrology, No. 23, UNESCO, Paris.

[5] Schanze, J. (2006) Food Risk Management-A Basic Framework. In: Schanze, J., et al., Eds., Flood Risk Management: Hazards, Vulnerability and Mitigation Measures, Springer, 1-20.

[6] Momani, N. and Fadil, S. (2010) Changing Public Policy Due to Saudi City of Jeddah Flood Disaster. Journal of Social Sciences, 6, 424-428.

[7] Ewea, A. (2010) Hydrological Analysis of Flooding Wastewater Lake in Jeddah, Saudi Arabia. JKAU: Met. Env. \& Arid Land Agric. Sci., 21, 125-144.

[8] Arnous, O., Aboulela, A. and Green, R. (2011) Geo-Environmental Hazards Assessment of the North Western Gulf of Suez, Egypt. Journal of Coastal Conservation, 15, 37-50. http://dx.doi.org/10.1007/s11852-010-0118-z

[9] Hall, W., Meadowcroft, C., Sayers, B. and Bramley, E. (2003) Integrated Flood Risk Management in England and Wales. Natural Hazard Review, ASCE, 4, 126-135. http://dx.doi.org/10.1061/(ASCE)1527-6988(2003)4:3(126)

[10] Hooijer, A., Klijn, F., Pedroli, B. and Van Os, A. (2004) Towards Sustainable Flood Risk Management in the Rhine and Meuse River Basins: Synopsis of the Findings of IRMA-SPONGE. River Research and Applications, 20, 343-357. http://dx.doi.org/10.1002/rra.781

[11] Singh, R., Kumar, R. and Tare, V. (2009) Variability of Soil Wetness and Its Relation with Floods over the Indian Subcontinent. Canadian Journal of Remote Sensing, 35, 85-97. http://dx.doi.org/10.5589/m08-079

[12] Abdel-Lattif, A. and Sherief, Y. (2012) Morphometric Analysis and Flash Floods of WadiSudr and Wadi Wardan, Gulf of Suez, Egypt: Using Digital Elevation Model. Arabian Journal of Geosciences, 5, 181-195. http://dx.doi.org/10.1007/s12517-010-0156-8

[13] (2003) Tourism Development Authority Report TDAR, Red Sea Sustainable Tourism Initiative. Land Use Management Plan, South Marsa Alam, Red Sea Coast, Egypt, 47 p.

[14] Ismail, I., Othman, A., Abd El-Latif, R. and Ahmed, A. (2010) Impact of Flash Flood on Development Potentials of Wadi Abu Ghusun, Eastern Desert, Egypt. Kuwait Journal of Science and Engineering, 37, 111-134.

[15] Tahoon, M. (2011) Hydrogeological and Environmental Study in the Area between Marsa Alam and Baranes Red Sea, Egypt. Ph.D. Thesis, Faculty of Science, South Valley University, Qena.

[16] Abdel Aziz, A. (1999) Structural Analysis of the Basement Complex in Wadi El Gemal Area, South Eastern Desert, Egypt. Ph.D. Thesis, South Valley University, Qena, 335.

[17] Abdalla, F. (2102) Mapping of Groundwater Prospective Zones Using Remote Sensing and GIS Techniques: A Case Study from the Central Eastern Desert, Egypt. Journal of African Earth Sciences, 70, 8-17.

[18] Makram, F. (1993) Hydrogeological and Hydrogeochemical Studies on Some Localities in South Eastern Desert, Egypt. Ph.D. Thesis, Faculty of Science, Suez Canal University, Egypt, 260 p.

[19] El Shamy, I. (1992) Towards the Water Management in Sinai. Proceedings of the 3rd Conference on Geology of Sinai Development, Ismailia, 63-70.

[20] Miller, N. (1953) A Quantitative Geomorphic Study of Drainage Basins Characteristics in Clinish Mountain Area, Verginia and Tenssesse. Columbia University, Technical Report No. 3, 30 p. 
Scientific Research Publishing (SCIRP) is one of the largest Open Access journal publishers. It is currently publishing more than 200 open access, online, peer-reviewed journals covering a wide range of academic disciplines. SCIRP serves the worldwide academic communities and contributes to the progress and application of science with its publication.

Other selected journals from SCIRP are listed as below. Submit your manuscript to us via either submit@scirp.org or Online Submission Portal.
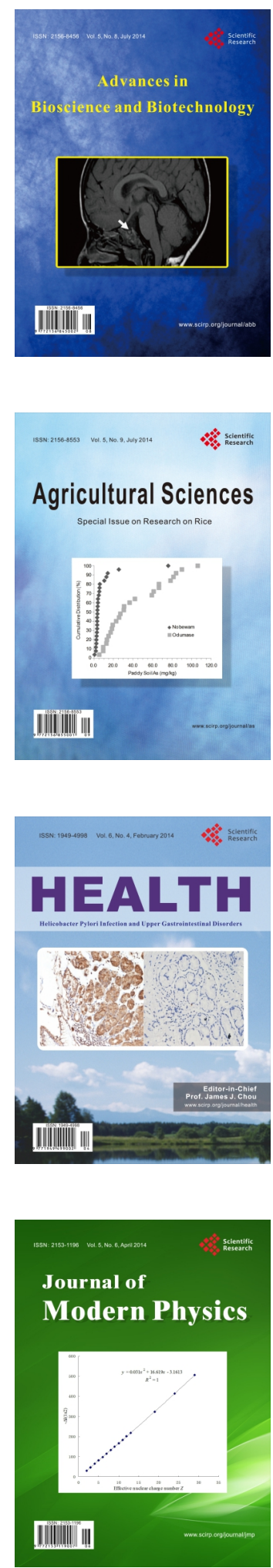
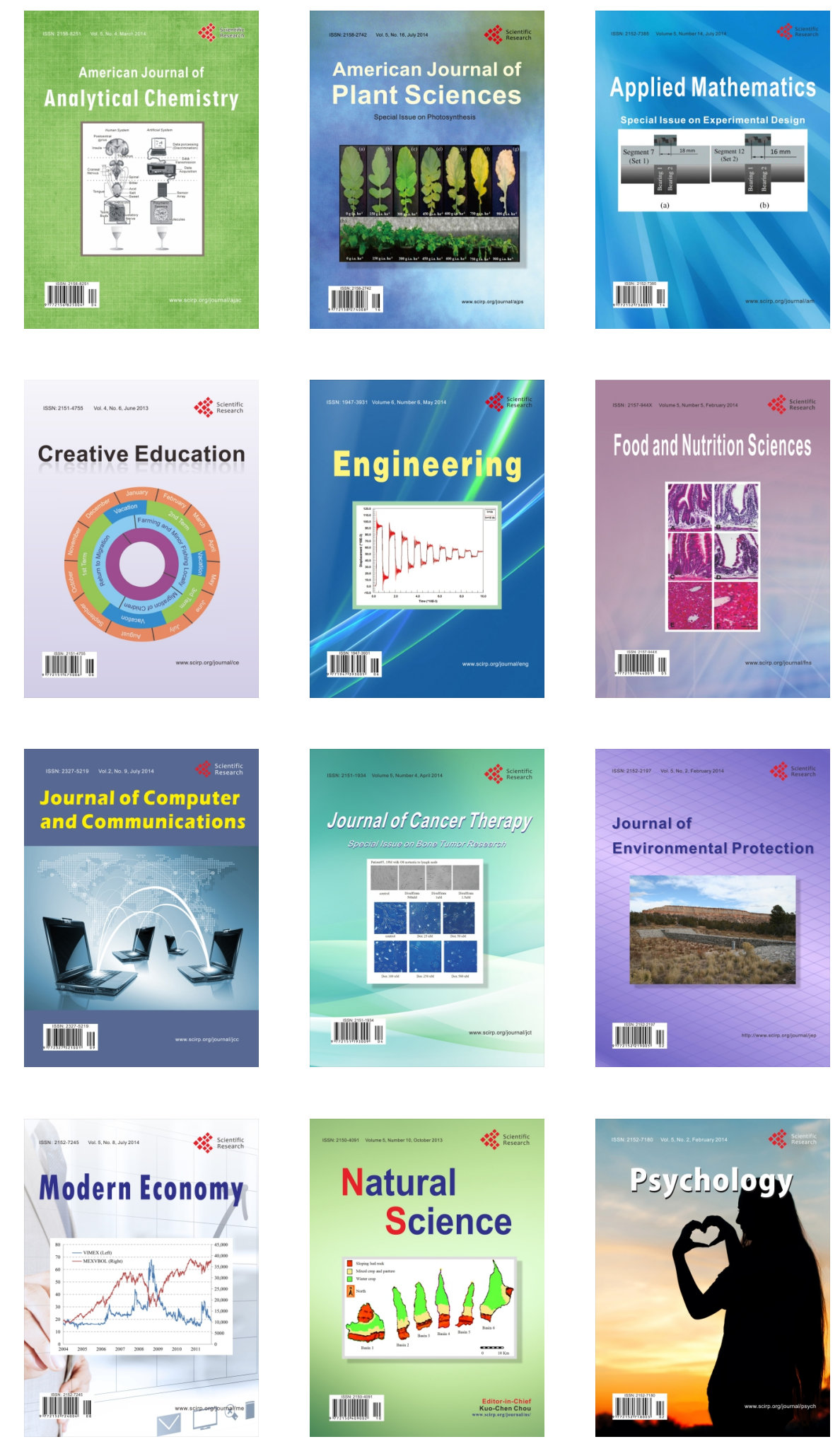